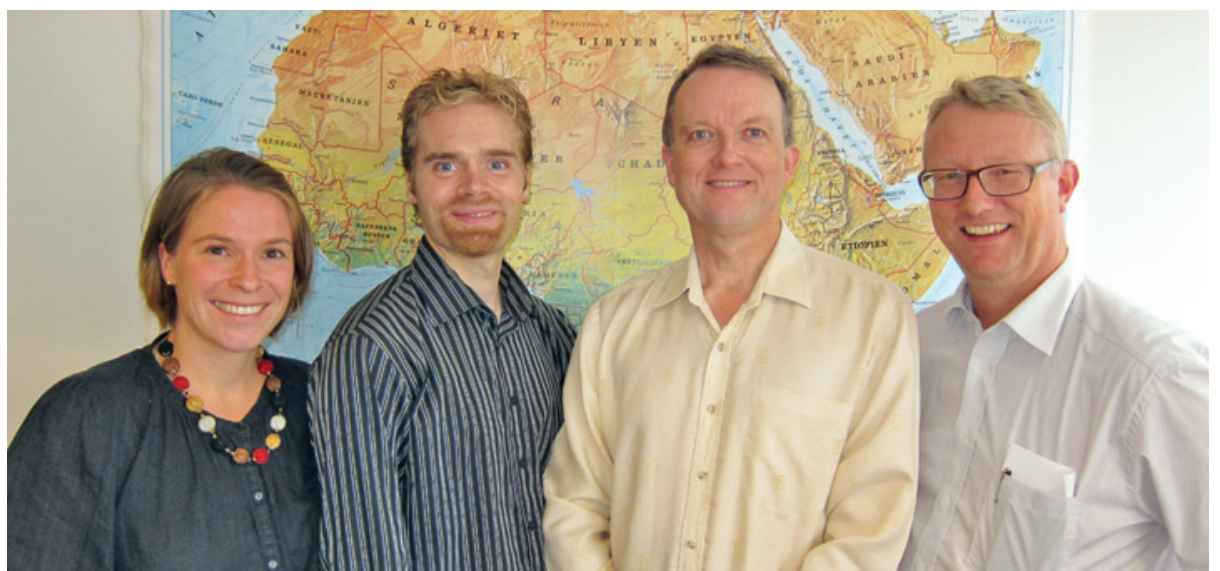

Ingunn M.S. Engebretsen, Lars T. Fadnes, Halvor Sommerfelt og Thorkild Tylleskär. Foto privat

\section{Ammeråd fra mødre fører til mer fullamming i Afrika}

Med en ukes opplæring kan kvinner i Afrika bli ammerådgivere og fremme fullamming og dermed barnehelsen. Det viser en ny, norskledet studie.

Studien ble gjennomført i Burkina Faso, Uganda og Sør-Afrika med 2579 morbarn-par (1). Til sammen 82 landsbyer eller byområder ble randomisert til intervensjonsområde eller kontrollområde. Kvinner $\mathrm{i}$ intervensjonsområdene fikk én ukes opplæring i amming. Deretter ga disse kvinnene ammeråd til mødre én gang før fødselen og fire ganger etterpå. Forekomsten av fullamming $\mathrm{i}$ alle landsbyene ble målt da barna var 12 og 24 uker.

I alle tre land var forekomsten av fullamming omtrent dobbelt så høy i intervensjonsgruppen som i kontrollgruppen. Forekomsten av fullamming ved 12 ukers alder var i Burkina Faso $79 \%$ i intervensjonsgruppen, mot $35 \%$ i kontrollgruppen, i Uganda $82 \%$ mot $44 \%$ og i Sør-Afrika $10 \%$ mot $6 \%$. Derimot kunne man ikke se noen forskjell i diaréforekomst mellom gruppene.

- Disse resultatene viser at kvinner etter kort opplæring kan gi råd som bidrar til mer utstrakt amming, sier professor Thorkild Tylleskär ved Senter for internasjonal helse i Bergen. - Denne type opplæring kan brukes for å få flere mødre til å fullamme i mange afrikanske land sør for Sahara.

Det at man ikke kunne påvise noen forskjell i forekomsten av diaré, kan tyde på at ammemønsteret $\mathrm{i}$ utgangspunktet er bedre i disse miljøene enn f.eks. i India, siden fullamming ikke gir samme dramatiske helsegevinster som vist i India.

I studien brukte vi et egenutviklet dataprogram, og vi samlet inn data direkte på håndholdte minidatamaskiner. Programmet finnes nå fritt tilgjengelig i en videreutviklet form for bruk på mobiltelefoner, sier Tylleskär.

\section{Helseforskning i Afrika}

Studien ble gjennomført av et forskningssamarbeid mellom tre europeiske universiteter (i Bergen, Uppsala og Montpellier) og fire afrikanske (i Burkina Faso, Uganda, Zambia og Sør-Afrika). Samarbeidet ble etablert ved at flere eksisterende bilaterale samarbeid slo seg sammen - Montpellier hadde et etablert samarbeid med Burkina Faso, Uppsala med Sør-Afrika og Bergen med Uganda og Zambia. Dermed var det helt fra starten av prosjektet et godt tillitsforhold mellom alle samarbeidspartnerne.

Prosjektet ble ledet av professor og barnelege Thorkild Tylleskär ved Senter for internasjonal helse, Universitetet i Bergen, som særlig arbeider med barnehelse, ernæring og hiv i Afrika. Han ønsker dessuten å utnytte den raske utviklingen innen mobiltelefoni til helseforskning. Flere andre kolleger fra senteret har deltatt i studien: forsker Ingunn Marie S. Engebretsen, professor Halvor Sommerfelt, forskerne Lars T. Fadnes og Bjarne Robberstad, professor Anne Nordrehaug-Åstrøm samt ph.d.-kandidatene Eli Fjeld Falnes og Jørn I.

Klungsøyr. Prosjektet har hittil resultert i over 20 artikler og seks doktorgrader, og flere artikler og doktorgrader er på gang.

\section{Erlend Hem}

erlend.hem@medisin.uio.no

Tidsskriftet

1. Tylleskär T, Jackson D, Meda N et al. Exclusive breastfeeding promotion by peer counsellors in sub-Saharan Africa (PROMISE-EBF): a clusterrandomised trial. Lancet 2011; 378: 420-7.
Litteratur
Ordforklaringer

Exclusive breastfeeding: «Fullamming» på norsk. Det betyr at et spedbarn ikke får noe annet enn morsmelk. Fullamming anbefales av WHO for friske barn opp til seks måneders alder fordi man i mange land har pleid å gi nyfødte og spedbarn forskjellige ting å drikke istedenfor morsmelk, noe som påvirker barnets vekst negativt.

Peer counsellor: På engelsk er en peer en som er likestilt (jf. peer review). En peer counsellor er en ufaglært rådgiver som fått kortvarig opplæring på et område, dvs. en «lekmannsrådgiver». I dette tilfellet hadde landsbyene selv utsett den eller de kvinnene som skulle delta i den ukelange ammingsopplæringen og som deretter ble landsbyens ammerådgiver.

Cluster-randomised trial: En grupperandomisert/klyngerandomisert intervensjonsstudie betyr at man istedenfor å randomisere enkeltindivider randomiserer befolkningsgrupper i gitte geografiske områder. Dette brukes især ved atferdsintervensjoner hvor intervensjonen ellers kunne påvirke kontrollgruppen. I dette tilfellet fikk intervensjonsområdene sin egen ammerådgiver, som så ga råd om amming til alle gravide og nyforløste mødre i byen. Det ville ha vært vanskelig å kunne gi denne intervensjonen til kun utvalgte mødre uten å påvirke de andre i samme område.

\section{THE LANCET}

"The two classes of antidepressants most likely to be prescribed for depression in Alzheimer's disease are no more effective than placebo."

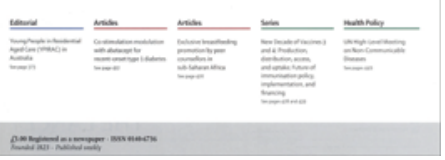

Artikkelen ble publisert 30.7. 2011 i The Lancet, som regnes som en av de «fem store» innen medisinsk publisering, ved siden av New England Journal of Medicine, JAMA, Annals of Internal Medicine og BMJ. (C) Lancet 2011, gjengitt med tillatelse fra Elsevier 